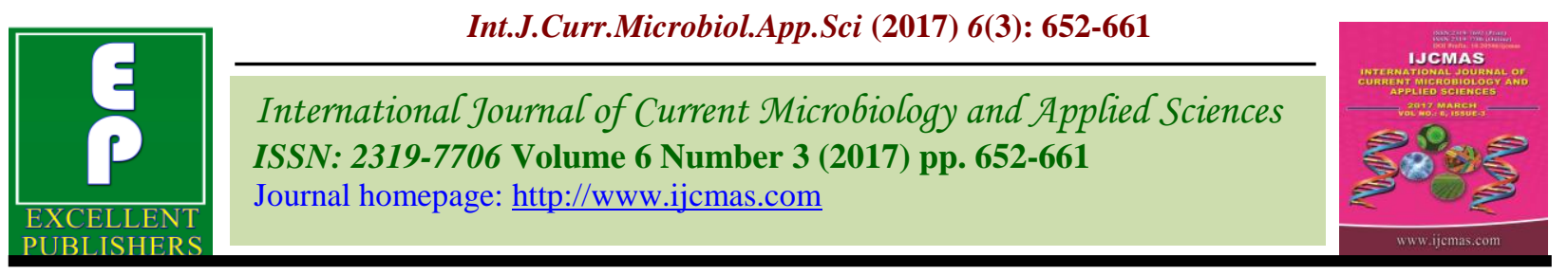

Original Research Article

https://doi.org/10.20546/ijcmas.2017.603.076

\title{
In vitro Evaluation of Fungicides, Botanicals and Bioagents against Peziotrichum corticolum causing Black Banded Disease of Mango
}

\author{
Chirag Gautam*, H. Virupaksha Prabhu and V.B. Nargund \\ Department of Plant Pathology, University of Agricultural Sciences, \\ Dharwad, 580005, Karnataka, India \\ *Corresponding author
}

\section{A B S T R A C T}

\begin{abstract}
Keywords
Black banded disease,

Peziotrichum corticolum, Fungicides, Plant extract, Bioagents.

Article Info

Accepted:

15 February 2017

Available Online:

10 March 2017

Among the tested five non-systemic, three combi- products, three systemic fungicides against Peziotrichum corticolum under laboratory condition, Bordeaux mixture, Copper oxychloride, Mancozeb, Carbendazim + Mancozeb, Hexaconazole + Zineb recorded maximum (100\%) mean percent inhibition of $P$. corticolum, followed by Cuprous hydroxide (96.39\%), Propiconazole (95.56\%), Captan + Hexaconazole (86.39\%), Difenconazole (80.74\%), Hexaconazole (74.07\%), Chlorothalonil (73.92\%). Among the five plant extracts (botanicals), maximum mean percent inhibition of mycelial growth $(22.78 \%)$ was recorded in neem kernel extract followed by Parthenium leaf extract $(21.48 \%)$, Lantana camara leaf extract $(13.70 \%)$, neem leaf extract (11.11\%). Least inhibition was recorded in Nerium leaf extract $(0.56 \%)$. Among all the tested bioagents, Trichoderma harzianum (77.22\%) was found to be significantly superior in inhibiting the mycelial growth of $P$. corticolum followed by Verticillium lecanii (45.83\%), Pseudomonas fluorescens (6.11\%) and Bacillus subtilis $(5.83 \%)$.
\end{abstract}

\section{Introduction}

Mango (Mangifera indica L.) commonly known as "king of fruits", is one of the world's most important and esteemed fruit (Basha et al., 2010). It is in high demand because of its strong aroma, delicious taste and high nutritive value. It occupies an area of 2.51 mha having annual production of 18.43 mt with the productivity of $7.3 \mathrm{t} / \mathrm{ha}$ in India and contributes $20.7 \%$ production share of major fruit crops in India. In Karnataka, the area under mango cultivation is 1.80 lakh ha with a production of $1.75 \mathrm{mt}$ and productivity is 9.7 t/ha (National Horticultural Database, 2014). Mango suffers from a number of diseases, because of diverse production conditions and the vast area grown. Some diseases take heavy toll on the crop and limit the production and productivity (Mamta and Singh, 2015).

Earlier black banded disease of mango was considered as a minor disease but for the last three to four years it is becoming severe in all the mango growing regions. The causal agent of black banded disease, Peziotrichum corticolum (Massee) Subramanian grows superficially on the bark of trees and forms large, dark black, irregular, girdle-like 
infection patches. The black velvety growth of fungus can also be found on the midribs and veins of leaves (Pandey and Dinesh, 2010). This disease is becoming severe day by day and no information available on the management of the disease by using fungicides, botanicals and bioagents. Present study was carried out to assess the efficacy of various fungicides, botanicals and bioagents against Peziotrichum corticolum under in vitro conditions.

\section{Materials and Methods}

The present study on black banded disease of mango was conducted during 2014-2015 at the Department of Plant Pathology, College of Agriculture, University of Agricultural Sciences, Dharwad. Dharwad is situated in northern transitional zone (Zone 8) of Karnataka state at $15^{\circ} 15^{\prime} \mathrm{N}$ latitude, $75^{\circ} 7^{\prime} \mathrm{N}$ longitude and at an altitude of $774.0 \mathrm{~m}$ above mean sea level. The material used and methodology adopted during the course of investigations are presented here.

In vitro evaluation of fungicides against $\boldsymbol{P}$. corticolum

The efficacy of five non-systemic, three combi- products and three systemic fungicides were tested against $P$. corticolum for growth inhibition on the potato dextrose agar media using poisoned food technique under in vitro conditions.

\section{Poisoned food technique}

Poisoned food technique (Shravelle, 1961) was followed to test the efficacy of the fungicides. The pathogen $P$. corticolum was grown on suitable solid medium in Petri plates for ten days prior to experiment. Fungicide suspension was prepared in that medium by adding requisite quantities of fungicides to obtain the desired concentration.
Poisoned medium was poured into sterilized petriplates. The plate without any fungicide served as control. Mycelial disc of $5 \mathrm{~mm}$ was taken with the help of sterilized cork borer, from the periphery of the ten days old culture and placed in the centre of petriplate and incubated at $28 \pm 2{ }^{\circ} \mathrm{C}$ till growth of the fungus reaches the periphery in the control plate. Three replications were maintained for each treatment. The colony diameter was measured in two directions and average was worked out. The percent inhibition of growth was calculated by using the formula given by Vincent (1947).

$I=\frac{C-T}{C} \times 100$

Where, $\mathrm{I}=$ Percent inhibition of mycelium $\mathrm{C}=$ Growth of mycelium in control $\mathrm{T}=$ Growth of mycelium in treatment

\section{In vitro evaluation of botanicals against $\boldsymbol{P}$.} corticolum

The present investigation was carried out to evaluate the extracts of five plant species (Table 1) to know the presence of fungitoxicant properties against $P$. corticolum.

\section{Preparation of plant based products}

Fresh healthy plant parts of $100 \mathrm{~g}$ (leaves or kernels) as indicated below were collected and washed with distilled water and air dried and followed by crushing in $100 \mathrm{ml}$ of sterile water. The crushed product was tied in muslin cloth and filtrate was collected. The prepared solution gave $100 \%$, which was further diluted to required concentrations of 5 and $10 \%$. The extracts were tested against $P$. corticolum on the PDA using poisoned food technique under in vitro condition as described earlier. The percent inhibition of 
growth of the test fungus was calculated by using the formula of Vincent (1947).

In vitro evaluation of bioagents against $P$. corticolum

The efficacy of four bioagents viz., Trichoderma harzianum, Bacillus subtilis, Pseudomonas fluorescens and Verticillium lecanii was tested against $P$. corticolum for radial growth inhibition on the potato dextrose agar media using dual culture technique under in vitro condition.

\section{Dual culture test}

Bioagents were evaluated for their efficacy following dual culture technique. The bioagents and the test fungus were inoculated side by side on a single Petridish containing solidified PDA medium. Five replications were maintained for each treatment with one control by maintaining only pathogen separately. They were incubated for 12 days. The diameter of the colony of both bioagents and the pathogen was measured in two directions and average was recorded. Percent inhibition of growth of the test fungus was calculated by using the formula of Vincent (1947).

\section{Results and Discussion}

In vitro evaluation of fungicides against $P$. corticolum

Screening of fungicides was done against $P$. corticolum under laboratory condition by following poisoned food technique as described in "Material and Methods". Five non-systemic fungicides, three combi products and three systemic fungicides were evaluated against $P$. corticolum in laboratory at four, four and three concentrations respectively by poisoned food technique.
In vitro evaluation of non systemic and combi fungicides against $\boldsymbol{P}$. corticolum

Data with respect to inhibition of mycelial growth of $P$. corticolum at four concentrations of five non-systemic fungicides and three combi products were recorded and results are presented in table 2. Data from the table revealed that, the efficacy of different nonsystemic fungicides, concentrations and their interaction on percent inhibition of mycelial growth of $P$. corticolum differed significantly.

Among all five non-systemic fungicides, maximum mean percent inhibition $(100 \%)$ of $P$. corticolum was recorded for Bordeaux mixture, Copper oxychloride and Mancozeb which were significantly superior to all other fungicides followed by Cuprous hydroxide (96.39\%). Least mean percent inhibition was noticed in Chlorothalonil (73.92\%). Bordeaux mixture, Copper oxychloride and Mancozeb recorded $100 \%$ inhibition of mycelial growth irrespective of concentration. For Cuprous hydroxide maximum percent inhibition of mycelial growth (100\%) was recorded at 0.25 and $0.3 \%$ concentration. Chlorothalonil showed maximum percent inhibition of mycelial growth $(84.44 \%)$ at $0.3 \%$ concentration.

At $0.3 \%$ concentration, Copper oxychloride, Cuprous hydroxide and Mancozeb recorded highest percent inhibition of mycelial growth $(100 \%)$ of fungus which was significantly superior to other fungicides followed by Chlorothalonil $(84.44 \%)$ which showed least inhibition of mycelial growth of fungus. At $0.15 \%$ concentration, maximum percent inhibition of mycelial growth $(100 \%)$ of the fungus was recorded in Copper oxychloride and Mancozeb. The least percent inhibition $(68.89 \%)$ of fungus was recorded for Chlorothalonil. 
Among the three combi products, Carbendazim + Mancozeb, Hexaconazole + Zineb recorded cent percent inhibitions which were significantly superior to all other fungicides followed by Captan + Hexaconazole (86.39\%) which was least among combi products.

Carbendazim + Mancozeb and Hexaconazole + Zineb recorded $100 \%$ inhibition of mycelial growth irrespective of concentration. Captan + Hexaconazole recorded $(78.89 \%)$ inhibition of mycelial growth at $0.15 \%$ concentration and $(92.22 \%)$ inhibition at $0.3 \%$ concentration.

In vitro evaluation of systemic fungicides against $P$. corticolum

Data with respect to inhibition of mycelial growth of $P$. corticolum at three concentrations of three systemic fungicides were recorded and results are presented in table 3. It was observed that, fungicides, concentrations and their interaction differed significantly with respect to inhibition of the mycelial growth of $P$. corticolum.

Among three systemic fungicides, maximum mean percent inhibition of growth of $P$. corticolum was observed in Propiconazole $(95.56 \%)$ which was significantly superior to all other fungicides followed by Difenconazole $(80.74 \%)$. The least mean percent inhibition of fungus was recorded in Hexaconazole (74.07\%).

Among the tested three concentrations, 0.15\% concentration of all fungicides was significantly found superior to 0.1 and 0.05 $\%$. At $0.05 \%$ concentration, maximum percent inhibition of mycelial growth $(93.33 \%)$ of the fungus was recorded in Propiconazole, followed by Difenconazole $(72.22 \%)$. The least percent inhibition of fungus was recorded in Hexaconazole
$(68.89 \%)$. At $0.1 \%$ concentration, maximum percent inhibition of mycelial growth $(93.33 \%)$ of the fungus was recorded in Propiconazole, followed by Difenconazole $(81.11 \%)$. The least percent inhibition of fungus was recorded in Hexaconazole ( $73.33 \%)$. At $0.15 \%$ concentration, maximum percent inhibition of mycelial growth $(100 \%)$ of the fungus was recorded in Propiconazole, followed by Difenconazole $(88.89 \%)$. The least $\%$ inhibition of fungus was recorded in Hexaconazole (80\%). At all the tested concentrations among systemic fungicides, Propiconazole recorded highest inhibition of mycelia growth.

Mycelial inhibition of $P$. corticolum by Propiconazole at $0.05 \%(93.33 \%)$ and $0.1 \%$ $(93.33 \%)$ remained on par with each other. Further mycelial inhibition by Hexaconazole at $0.1 \%$ concentration $(73.33 \%)$ remained on par with Difenconazole at $0.05 \%(72.22 \%)$. Further mycelial inhibition by Hexaconazole at $0.15 \%$ concentration $(80 \%)$ remained on par with Difenconazole at $0.1 \%(81.11 \%)$.

\section{In vitro evaluation of botanicals against $P$. corticolum}

An experiment was conducted to assess the antifungal activity of five plant extracts as described under "Material and Methods" and the results are presented in table 4 . The effect of plant extracts on the percent inhibition of mycelial growth of $P$. corticolum at three concentrations differed significantly.

Among the five plant extracts, maximum mean percent inhibition of mycelial growth $(22.78 \%)$ was recorded in neem kernel extract which was significantly superior to other all treatments tested, followed by Parthenium leaf extract $(21.48 \%)$, Lantana camara leaf extract (13.70\%), neem leaf extract (11.11\%). Least inhibition was recorded in Nerium leaf extract $(0.56 \%)$. 
At $10 \%$ concentration of plant extracts, maximum of $30 \%$ inhibition of mycelial growth was recorded in neem kernel extract followed by Parthenium leaf extract $(22.96 \%)$, neem leaf extract $(17.78 \%)$ and Lantana camara leaf extract (15.19\%). Least inhibition was recorded in Nerium leaf extract $(10 \%)$. At $5 \%$ concentration of plant extracts, maximum of $20 \%$ inhibition of mycelial growth was recorded in Parthenium leaf extract followed by neem kernel extract (15.56\%), Lantana camara leaf extract $(12.22 \%)$ and neem leaf extract (4.44\%). Least inhibition was recorded in Nerium leaf extract $(3.33 \%)$.

Mycelial inhibition of $P$. corticolum by Nerium leaf extract at $5 \%(3.33 \%)$ remained on par with neem leaf extract at $5 \%(4.44 \%)$. Further at $10 \%$, mycelial inhibition by Lantana camara leaf extract (15.19\%) remained on par with neem leaf extract (17.78\%). Further mycelial inhibition by neem kernel extract at $5 \% \quad(15.56 \%)$ remained on par with Lantana camara leaf extract at $10 \%(15.19 \%)$.

\section{In vitro evaluation of bioagents against $P$. corticolum}

Efficacy of bacterial and fungal bioagents was studied under in vitro condition by following dual culture method as described in "Material and Methods" and the results are presented in table 5. There were significant differences among all the tested bioagents.

Trichoderma harzianum $(77.22 \%)$ was found to be significantly superior in inhibiting the mycelial growth of $P$. corticolum followed by Verticillium lecanii (45.83\%) and Pseudomonas fluorescens (6.11\%). The least inhibition of mycelial growth of $P$. corticolum was recorded in Bacillus subtilis (5.83\%). Further Pseudomonas fluorescens and Bacillus subtilis remained on par with each other.
In vitro evaluation of fungicides against $P$. corticolum

Use of fungicides to manage different plant diseases is an old age practice. Fungicides are found as best option to manage plant disease in case of epidemic outbreak. These fungicides must be used judiciously according to the need and kind of organism involved. It is necessary to evaluate the fungicides under in vitro conditions to know their efficacy, and initiate spray schedule in field conditions.

Among all three groups of fungicides, nonsystemic fungicides and combi products were found to be more effective than systemic fungicides. Three non systemic fungicides namely Bordeaux mixture, Copper oxychloride, Mancozeb and two combi products namely Carbendazim + Mancozeb and Hexaconazole + Zineb recorded $100 \%$ inhibition of mycelial growth of $P$. corticolum. Least mean percent inhibition was noticed in Chlorothalonil (73.92\%). Among three systemic fungicides, maximum mean percent inhibition of growth of $P$. corticolum was observed in Propiconazole (95.56\%) and least mean percent inhibition of fungus was recorded in Hexaconazole (74.07\%).

At higher concentration most of the fungicides inhibited maximum mycelial growth but decreased with reduced concentration. Naik and Hiremath (1986) reported the complete inhibition of mycelial growth of Colletotrichum gloeosporioides with Copper oxychloride (0.1, 0.2 and $0.3 \%$ ). Ashoka (2005) reported that Carbendazim + Mancozeb recorded $100 \%$ inhibition of mycelial growth of Colletotrichum gloeosporioides. Contrary to it, Venkataravanappa and Nargund (2002) reported tricyclazole as very effective under laboratory condition against Colletotrichum gloeosporioides among all the tested fungicides. 
In vitro evaluation of botanicals against P.corticolum

Extensive use of fungicides has led to various environmental problems, human health and their persistence in the fruits. To sort out these problems botanicals were tested in laboratory against $P$. corticolum. Continuous use of chemical fungicides in the management of disease also brought new problems with them. Amongst them is pollution of air, water, soil, residual toxicity, development of resistance in the pathogen against chemicals there by the need to apply them more with their escalating prices and harmful effects on non target organisms. Consequently, fungicides have been alarming the development of harmful environment for human beings. Contrary to the problems associated with use of synthetic chemicals, botanicals are environmentally non-pollutive, renewable, in-exhaustible, indigenously available, thus readily biodegradable relatively cost effective and hence constitute as a suitable plant protection in the strategy of integrated disease management. Hence, screening of plant products for its effective antifungal activity against the pathogen is essentially required to minimize the use of fungicides and considered as one of the components in the integrated disease management (Khadar,
1999; Nagesh, 2000 and Jayalakshmi, 2010). At $10 \%$ concentration of plant extracts, maximum of $30 \%$ inhibition of mycelial growth was recorded in neem kernel extract and least inhibition was recorded in Nerium leaf extract (10\%).

At $5 \%$ concentration of plant extracts, maximum of $20 \%$ inhibition of mycelial growth was recorded in Parthenium leaf extract followed by neem kernel extract $(15.56 \%)$ and least inhibition was recorded in Nerium leaf extract (3.33\%).

The effectiveness of Neem kernel extract as a pesticide may be due to phyto-constituents like alkaloids, glycosides, flavonoids and saponins which are antimicrobial in nature. Further, Shivapuri et al., (1997) noticed Azadirachta indica, as more fungitoxic among ten plant extracts.

\section{In vitro evaluation of bioagents against P.corticolum}

Regular use of synthetic chemicals / fungicides in mango has been a norm in many orchards that brings with it many hazards such as pesticide residue, development of resistant strains among the pathogen, ecological consideration etc.

Table.1 Plant species and their parts used for in vitro evaluation

\begin{tabular}{|c|l|l|}
\hline Sl. No. & Plants product/extract & Plant part used \\
\hline 1. & Lantana camara & Leaf \\
\hline 2. & Neem kernel extract & Kernel \\
\hline 3. & Neem leaf extract & Leaf \\
\hline 4. & Nerium oleander & Leaf \\
\hline 5. & Parthenium hysterophorus & Leaf \\
\hline
\end{tabular}


Table.2 In vitro evaluation of contact fungicides and combi -products against mycelial growth of Peziotrichum corticolum

\begin{tabular}{|c|c|c|c|c|c|c|}
\hline \multirow{3}{*}{ Common name } & \multirow{3}{*}{ Trade name } & \multicolumn{5}{|c|}{ Inhibition (\%) } \\
\hline & & \multicolumn{4}{|c|}{ Concentrations (\%) } & \multirow{2}{*}{ Mean } \\
\hline & & 0.15 & 0.20 & 0.25 & 0.30 & \\
\hline \multicolumn{7}{|l|}{ Contact fungicides } \\
\hline Chlorothalonil & $\begin{array}{l}\text { Kavach } 75 \% \\
\text { WP }\end{array}$ & $\begin{array}{l}68.89^{\#} \\
(56.08)^{*}\end{array}$ & $\begin{array}{c}74.44 \\
(59.61)\end{array}$ & $\begin{array}{c}81.11 \\
(64.21)\end{array}$ & $\begin{array}{c}84.44 \\
(66.74)\end{array}$ & $\begin{array}{c}73.92 \\
(61.66)\end{array}$ \\
\hline Copper oxychloride & $\begin{array}{l}\text { Blitox } 50 \% \\
\text { WP }\end{array}$ & $\begin{array}{l}100.00 \\
(89.96)\end{array}$ & $\begin{array}{l}100.00 \\
(89.96)\end{array}$ & $\begin{array}{l}100.00 \\
(89.96)\end{array}$ & $\begin{array}{l}100.00 \\
(89.96)\end{array}$ & $\begin{array}{l}100.00 \\
(89.96)\end{array}$ \\
\hline Cuprous hydroxide & $\begin{array}{l}\text { Kocide } 77 \% \\
\text { WP }\end{array}$ & $\begin{array}{c}92.22 \\
(73.78)\end{array}$ & $\begin{array}{c}93.33 \\
(75.01)\end{array}$ & $\begin{array}{l}100.00 \\
(89.96)\end{array}$ & $\begin{array}{l}100.00 \\
(89.96)\end{array}$ & $\begin{array}{c}96.39 \\
(82.18)\end{array}$ \\
\hline Mancozeb & $\begin{array}{l}\text { Indofil M-45 } \\
75 \% \mathrm{WP}\end{array}$ & $\begin{array}{l}100.00 \\
(89.96)\end{array}$ & $\begin{array}{l}100.00 \\
(89.96)\end{array}$ & $\begin{array}{l}100.00 \\
(89.96)\end{array}$ & $\begin{array}{l}100.00 \\
(89.96)\end{array}$ & $\begin{array}{l}100.00 \\
(89.96)\end{array}$ \\
\hline \multicolumn{7}{|l|}{ Combiproducts } \\
\hline $\begin{array}{l}\text { Carbendazim } 12 \%+ \\
\text { Mancozeb } 63 \% \text { WP }\end{array}$ & Saaf $75 \%$ WP & $\begin{array}{l}100.00 \\
(89.96)\end{array}$ & $\begin{array}{l}100.00 \\
(89.96)\end{array}$ & $\begin{array}{l}100.00 \\
(89.96)\end{array}$ & $\begin{array}{l}100.00 \\
(89.96)\end{array}$ & $\begin{array}{l}100.00 \\
(89.96)\end{array}$ \\
\hline $\begin{array}{l}\text { Hexaconazole } 4 \%+ \\
\text { Zineb } 68 \% \text { WP }\end{array}$ & $\begin{array}{l}\text { Avatar } 72 \% \\
\text { WP }\end{array}$ & $\begin{array}{l}100.00 \\
(89.96)\end{array}$ & $\begin{array}{l}100.00 \\
(89.96)\end{array}$ & $\begin{array}{l}100.00 \\
(89.96)\end{array}$ & $\begin{array}{l}100.00 \\
(89.96)\end{array}$ & $\begin{array}{l}100.00 \\
(89.96)\end{array}$ \\
\hline $\begin{array}{l}\text { Captan } 70 \%+ \\
\text { Hexaconazole 5\% WP }\end{array}$ & $\begin{array}{l}\text { Taqat } 75 \% \\
\text { WP }\end{array}$ & $\begin{array}{c}78.89 \\
(62.23)\end{array}$ & $\begin{array}{r}85.56 \\
(67.67)\end{array}$ & $\begin{array}{l}88.89 \\
(70.50)\end{array}$ & $\begin{array}{c}92.22 \\
(73.80)\end{array}$ & $\begin{array}{c}86.39 \\
(68.65)\end{array}$ \\
\hline Source & & \multicolumn{2}{|c|}{ Fungicides (F) } & \multicolumn{2}{|c|}{$\begin{array}{c}\text { Concentration } \\
\text { (C) }\end{array}$} & $\times \mathbf{C}$ \\
\hline S.Em. \pm & & \multicolumn{2}{|c|}{0.13} & \multicolumn{2}{|l|}{0.10} & .26 \\
\hline CD at $1 \%$ & & \multicolumn{2}{|c|}{0.49} & \multicolumn{2}{|l|}{0.37} & 0.98 \\
\hline \multirow{3}{*}{ Bordeaux mixture } & \multirow{3}{*}{ - } & \multicolumn{4}{|c|}{ Concentrations (\%) } & \multirow{2}{*}{ Mean } \\
\hline & & 0.50 & 0.75 & 1.00 & 1.25 & \\
\hline & & $\begin{array}{l}100.00 \\
(89.96)\end{array}$ & $\begin{array}{l}100.0 \\
(89.96\end{array}$ & $\begin{array}{r}100.00 \\
(89.96)\end{array}$ & $\begin{array}{l}100.00 \\
(89.96)\end{array}$ & $\begin{array}{l}100.00 \\
(89.96)\end{array}$ \\
\hline
\end{tabular}

$*=$ Arcsine values

${ }^{\#}=$ Mean of three replications 
Table.3 In vitro evaluation of systemic fungicides against mycelial growth of Peziotrichum corticolum

\begin{tabular}{|c|c|c|c|c|c|}
\hline \multirow{3}{*}{ Common name } & \multirow{3}{*}{ Trade name } & \multicolumn{4}{|c|}{ Inhibition (\%) } \\
\hline & & \multicolumn{3}{|c|}{ Concentration (\%) } & \multirow{2}{*}{ Mean } \\
\hline & & 0.05 & 0.10 & 0.15 & \\
\hline Difenconazole & Score $25 \%$ EC & $\begin{array}{c}72.22^{\#} \\
(58.17)^{*}\end{array}$ & $\begin{array}{c}81.11 \\
(64.21)\end{array}$ & $\begin{array}{c}88.89 \\
(70.50)\end{array}$ & $\begin{array}{c}80.74 \\
(64.29)\end{array}$ \\
\hline Hexaconazole & Contaf $5 \% \mathrm{EC}$ & $\begin{array}{c}68.89 \\
(56.08)\end{array}$ & $\begin{array}{c}73.33 \\
(58.89)\end{array}$ & $\begin{array}{c}80.00 \\
(63.41)\end{array}$ & $\begin{array}{c}74.07 \\
(59.46)\end{array}$ \\
\hline Propiconazole & Tilt $25 \%$ EC & $\begin{array}{c}93.33 \\
(75.01)\end{array}$ & $\begin{array}{c}93.33 \\
(75.01)\end{array}$ & $\begin{array}{l}100.00 \\
(89.96)\end{array}$ & $\begin{array}{c}95.56 \\
(79.99)\end{array}$ \\
\hline Source & & \multicolumn{2}{|c|}{ S.Em \pm} & \multicolumn{2}{|c|}{ CD at $1 \%$} \\
\hline $\begin{array}{c}\text { Fungicides (F) } \\
\text { Concentration (C) } \\
\mathbf{F} \times \mathbf{C}\end{array}$ & & & & & \\
\hline
\end{tabular}

*Arcsine transformed values

${ }^{\#}=$ Mean of five replications

Table.4 In vitro evaluation of botanicals/plant extracts against mycelial growth of Peziotrichum corticolum

\begin{tabular}{|c|c|c|c|c|c|}
\hline \multirow{3}{*}{$\begin{array}{c}\text { Sl. } \\
\text { No. }\end{array}$} & \multirow{3}{*}{ Name of plant } & \multirow{3}{*}{$\begin{array}{c}\text { Plant } \\
\text { part } \\
\text { used }\end{array}$} & \multicolumn{3}{|c|}{ Per cent Inhibition } \\
\hline & & & \multicolumn{2}{|c|}{ Concentration (\%) } & \multirow{2}{*}{ Mean } \\
\hline & & & 5 & 10 & \\
\hline 1. & $\begin{array}{l}\text { Lantana } \\
\text { camara }\end{array}$ & Leaf & $\begin{array}{l}12.22^{\#} \\
(20.44)^{*}\end{array}$ & $\begin{array}{c}15.19 \\
(22.90)\end{array}$ & $\begin{array}{r}13.70 \\
(21.67)\end{array}$ \\
\hline 2. & $\begin{array}{l}\text { Neem kernel } \\
\text { extract }\end{array}$ & Kernel & $\begin{array}{c}15.56 \\
(23.21)\end{array}$ & $\begin{array}{c}30.00 \\
(33.20)\end{array}$ & $\begin{array}{l}22.78 \\
(28.20)\end{array}$ \\
\hline 3. & $\begin{array}{l}\text { Neem leaf } \\
\text { extract }\end{array}$ & Leaf & $\begin{array}{c}4.44 \\
(12.10)\end{array}$ & $\begin{array}{l}17.78 \\
(24.92)\end{array}$ & $\begin{array}{c}11.11 \\
(18.51)\end{array}$ \\
\hline 4. & $\begin{array}{l}\text { Nerium } \\
\text { oleander }\end{array}$ & Leaf & $\begin{array}{c}3.33 \\
(10.06)\end{array}$ & $\begin{array}{c}10.00 \\
(18.36)\end{array}$ & $\begin{array}{c}6.67 \\
(14.21)\end{array}$ \\
\hline 5. & $\begin{array}{l}\text { Parthenium } \\
\text { hysterophorus }\end{array}$ & Leaf & $\begin{array}{c}20.00 \\
(26.55)\end{array}$ & $\begin{array}{c}22.96 \\
(28.61)\end{array}$ & $\begin{array}{l}21.48 \\
(27.58)\end{array}$ \\
\hline \multicolumn{3}{|c|}{ Mean } & $\begin{array}{c}11.11 \\
(18.47)\end{array}$ & $\begin{array}{c}19.19 \\
(25.60)\end{array}$ & $\begin{array}{l}15.15 \\
(22.04)\end{array}$ \\
\hline \multicolumn{3}{|c|}{ Source } & $\begin{array}{c}\text { Botanicals } \\
\text { (B) }\end{array}$ & $\begin{array}{c}\text { Concentration } \\
\text { (C) }\end{array}$ & $\mathbf{B} \times \mathbf{C}$ \\
\hline \multicolumn{3}{|c|}{ SEm \pm} & 0.69 & 0.43 & 0.97 \\
\hline \multicolumn{3}{|c|}{ CD at $1 \%$} & 2.76 & 1.75 & 3.90 \\
\hline
\end{tabular}

\#= Mean of five replications

$*=$ Arcsine transformed values 
Table.5 In vitro evaluation of bioagents against Peziotrichum corticolum

\begin{tabular}{|l|l|c|}
\hline Sl. No. & Bioagent & Per cent inhibition \\
\hline 1. & Bacillus subtilis & $\begin{array}{c}5.83^{\#} \\
(13.82)^{*}\end{array}$ \\
\hline 2. & Pseudomonas fluorescens & $\begin{array}{c}6.11 \\
(14.19)\end{array}$ \\
\hline 3. & Trichoderma harzianum & $\begin{array}{c}77.22 \\
(61.48)\end{array}$ \\
\hline 4. & Verticillium lecanii & $\begin{array}{c}45.83 \\
(42.58)\end{array}$ \\
\hline S.Em \pm & & 1.03 \\
\hline CD at $1 \%$ & 4.29 \\
& $*$ Mean of five replications \\
$*$ & Arcsine transformed values
\end{tabular}

Use of bioagents, nowadays, is best and has been most emphasized and widely accepted practice as it is environmentally safe and can overcome the residual problems associated with heavy use of fungicides for management disease. Hence, the present investigation was taken up to screen the bioagents for effective management of black banded disease of mango.

Among the bioagents tried during present investigation Trichoderma harzianum was found to be best in inhibiting mycelial growth of $P$. corticolum (77.22\%) followed by Verticillium lecanii (45.83\%) and Pseudomonas fluorescens $(6.11 \%)$ and least percent inhibition of mycelial growth was observed in Bacillus subtillis (5.83\%).

Present studies recorded significant mycoparasitism of Trichoderma harzianum on $P$. corticolum that caused lysis of the hyphae in vitro. Result of the experiment was further supported by Watve et al., (2009), according to them; maximum inhibition of Colletotrichum gloeosporioides causing leaf spot disease of jatropha was achieved by Trichoderma harzianum.

\section{References}

Ashoka, S. 2005. Studies on fungal pathogens of vanilla with special reference to Colletotrichum gloeosporioides (Penz.) Penz. and Sacc. M.Sc. (Agri.) Thesis, Uni. Agric. Sci., Dharwad, India.

Basha S.T., Suvarna, J., Hemalatha, T.M. and Reddy, N.P.E. 2010. Compatibility of native potential bioagents with different fungicides against Colletotrichum gloeosporioides Penz. causing mango anthracnose. The Bioscan, 5(1): 19-20.

Jayalakshmi, K. 2010. Studies on anthracnose of pomegranate caused by Colletotrichum gloeosporioides (Penz.) Penz. \& Sacc. M.Sc. (Agri.) Thesis, Univ. Agril. Sci., Dharwad, India.

Khadar, S.K. 1999. Management of foliar diseases of groundnut with special reference to botanicals. M.Sc. (Agri.) Thesis, Univ. Agril. Sci., Dharwad, India. 
Mamta and Singh K.P. 2015. Disease assessment key for powdery mildew of mango. The Bioscan, 10(4): 1777-1781.

Nagesh, G.K. 2000. Investigation on sunflower rust caused by Puccinia helianthi Schw. M.Sc. (Agri.) Thesis, Uni. Agric. Sci., Dharwad, India.

Naik, M.K. and Hiremath, P.C. 1986. Unrecorded pathogen on betelvine causing anthracnose. Curr. Sci., 55: 625 .

National Horticulture Database. 2014. http://nhb.gov.in/area-pro/ NHB Database 2015. (retrieved on 21.9.2015).

Pandey, S.N. and Dinesh, M.R. 2010. Mango, Indian Council of Agricultural Research, New Delhi.

Shivapuri, A., Sharma, O.P. and Jamaria, S.L. 1997. Fungitoxic properties of plant extracts against pathogenic fungi. $J$. Mycol. Pl. Pathol., 27: 429.
Shravelle, V.G. 1961. The nature and use of modern fungicides. Burges Publication Company, Minneosota, USA, Pp. 308.

Venkataravanappa, V. and Nargund, V.B. 2002. Evaluation of different fungicides against Colletotrichum gloeosporioides causal organism of anthracnose of mango. Paper presented on Plant disease scenario in southern India. Univ. Agric. Sci., Bangalore, Аnnu. Meet. Symp., 19-21. pp. 56.

Vincent, J.M. 1947. Distortion of fungal hyphae in the presence of certain inhibitors. Nature, 159: 850.

Watve, Y.G., Diwakar, M.P., Kadam, J.J., Sawant, U.K. and Mundhe, V.G. 2009. Effect of different chemicals, plant extracts and bioagents against Colletotrichum gloeosporioides causing leaf spot disease of jatropha. $J$. Pl. Dis. Sci., 4(2):199-203.

\section{How to cite this article:}

Chirag Gautam, H. Virupaksha Prabhu and Nargund V.B. 2017. In Vitro Evaluation of Fungicides, Botanicals and Bioagents against Peziotrichum corticolum causing Black Banded Disease of Mango. Int.J.Curr.Microbiol.App.Sci. 6(3): 652-661. doi: https://doi.org/10.20546/ijcmas.2017.603.076 